\title{
CONSTITUTIONAL LAW: AN OVERVIEW OF THE ISLAMIC APPROACH AND ITS CONTEMPORARY RELEVANCE
}

\author{
Abdul Samat Musa* \\ Faculty of Syariah and Law, Universiti Sains Islam Malaysia (USIM), Malaysia
}

\begin{abstract}
Constitutional law (al-fiqh al-dusturi) is one of the important aspects of shariah. However, it has not been given due elaboration by Muslim jurists and modern scholars, unlike other branches of Islamic law. Its potentials have not been fully explored and developed for the practical purposes in a modern system of government. However, generic studies on Islamic state abound, but very little has been devoted to the study of the principles of Islamic state in relation to constitutional law. This paper is an attempt to examine this dimension, and provide an overview of the Islamic approach to constitutional law, by analyzing some Islamic principles, seen in a contemporary context. Since principles of Islamic state permeate constitutional law, understanding of the former is inevitable; they can also be regarded as Islamic constitutional principles. This research demonstrates that Islamic constitutional principles, while being faithful to basic tenets of religion, are flexible enough to accommodate the changing needs and varied applications in modern times. This aspect of the law requires further development by both shariah and constitutional experts.
\end{abstract}


Keywords: Constitutional law, overview, Islamic approach, Contemporary relevance

\section{Introduction}

Islamic religion (al-din al-Islami) is a complete guidance and mercy to the entire universe. It comprises three main important components: 'aqidah (fundamental religious beliefs and matters related to faith); shari'ah ( law and regulations governing various relationships, either in the form of specific rules or guiding principles); and akhlaq (morality or non-legal rules or ethical principles). Thus, it governs all aspects of human relationships and dealings, whether among the people themselves, and between the people and the universe, people and God, relations among nations, and between national authority and the ruled, including matters pertaining to constitutional and administrative law (al-fiqh al-dusturi wa al-idari) or those concerning state and government (Yusuf al-Qaradawi, 1991, 143). The concept of relationship between Islam and state has long been the subject of discourse among both classical jurists and modern scholars. Constitutional law is part of the formation and constituents of state and its legal system. However, the discipline of constitutional law appears to be less developed compared to other branches of Islamic law. There are some issues or misconceptions revolving around the Islamic concept of state in general and constitutional law in particular. The purpose of this paper is to examine the Islamic approach to constitutional law, including the concept of state, since both are interrelated, and ascertain its great potential and practical relevance in addressing current challenges and needs, in relation to contemporary systems of government.

\section{Definition of Constitutional Law}

There is no uniform definition of 'constitution', either written or unwritten, given by constitutional lawyers. The written type refers to constitutional rules which are compiled in a single document, whereas for the unwritten one, such rules are scattered, and to be found in many sources, such as the Constitution of the United Kingdom. In a sense it may be defined as 'the document in which are set out the rules governing the composition, powers, and methods of operation of the main institutions of government, and the general principles applicable to their relations to the citizens'. Its drafting may take into account considerations of circumstances and the special problems faced by the state. It is a skeleton, a framework 
which has to be filled out with detailed rules and practices (Sir Ivor Jennings, 1973, 33, 35). Although the definition of a constitution by some constitutional lawyers varies in terms of its formulation, the kernel of a constitution basically embodies the fundamental structure or form of the state and basic provisions relating to a system of government that consists, mainly of three organs of state, namely the executive, legislative and judiciary, their relationships and respective functions and powers, and rights of the rulers and citizens.

A state requires constitution and constitutional principles in order to show the direction and the way the state should operate. Essentially, definition of constitutional law is universal, and the Muslim scholars seem to have used the same definition in terms of its scope and coverage. What is different in the context of Islam is its basic contents and philosophy.

\section{Islam, State and the Constitution}

In Islam, there is a close relationship between religion (din) and state (daulah). Islamic literature on this subject abounds. Any attempt to isolate issues of state or politics from religion was futile, and never gained recognition from Islamic authorities. The first attempt to deny the existence of this relationship in modern time was made by Shaikh 'Ali 'Abd alRaziq in his book entitled al-Islam wa Usul al-Hukmi (Islam and Fundamental Principles of Government). It was published in 1925, about a year after the abolition of the Ottoman Caliphate in Turkey in 1924. He claimed that the message of Islam (Risalat al-Islam) had nothing to do with the establishment of state. His views were, however, severely criticised and refuted by many prominent Muslim scholars in a number books, and widely considered an affront to the precepts of Islamic religion and alien to the established Islamic political thought. The books especially authored which have often been referred to by many commentators, to rebut the above claims include, for example, Naqd Kitab al-Islam wa Usul al-Hukm by Syaikh Muhammad al-Khidr Husain; Haqiqat al-Islam wa Usul al-Hukm by Syaikh Muhammad Bakhit al-Muti'i and Mabadi' Nizam al- Hukm by Professor 'Abdul Hamid Mutawalli (1974). The relation between the state and religion is, according to AlGhazali, like twin sisters, religion being the foundation of human society and the ruler of the state is its preserver (Haroon Khan Sherwani, 1942, 211).

The fact that the principles of government and constitutional rules forming an integral part of the religion of Islam, has never been the subject of disagreement before and after the appearance of Syaikh 'Ali 'Abd al-Raziq's book (Hamid Enayat, 1982). The creation of the 
Islamic state together with the written Madinah Constitution by the Prophet at Madinah represents the earliest illustration of an inextricable link between religion and politics in Islam. The Prophet introduced the first constitutional government since the seventh century (Hamidullah, ).The constitutional practice was followed and developed by the four Khulafa' al-Rasyidun ( Rightly guided Caliphs)(632-661).The idea of Islamic state, government and constitution has remained alive in the thought and treatises of Muslim political thinkers and reformists or Islamic movements throughout the history of Islam, and more recently, works continued to be published on this subject in a more articulated manner, and by using a contemporary analysis, for example, a book on Islamic law and constitution by Abul A'la Maududi from Pakistan.

State, as defined under international law, consists of several elements: Territory, sovereignty, people or inhabitants and political authority (Abdul Ghafur Hamid@Khin Maung Sein, 2007, 87). The state requires a constitution, whether written or unwritten and an effective government (Mohamed Salleh Abas, 1968, 2-5). Muslim political or constitutional theorists in analysing the elements that constitute a state have used the same universally recognised criteria, but with an added component i.e. submission to the requirements of the religion of Islam (tahkim al-Islam), or phrased in such other different ways as hakimiyyatullah (sovereignty of God) or siyadah al-shari'ah (supremacy of shariah). This new element has often been misinterpreted as akin to a theocratic system of government in Western thought. The state is claimed to have been completely controlled by God that denies the involvement of the people in government and their freedoms, which is considered inimical to a democracy. Western view of theocracy is contrary with the genuine concept of state and government in Islam.

\section{Islam and Constitutionalism}

The modern idea of constitutionalism, has often been referred to the English political philosopher John Locke, who believed that government should be limited by law (Kevin Y.L. Tan, 2014, 1). As stated earlier, the idea of constitution and constitutionalism is not alien to Islam and its concept and approaches are universal. It can be argued that the Islamic concept of limited government (hukumah muqayyadah) (Mustafa Kamal Wasfi, 1994, 14) preceded the western history of constitutionalism. There is even a possibility of some influence of Islamic thinking on the relationship between subjects and state (C. G. Weeramantry, 1988, 
105) on Western political thought, which later had an impact on the theory and practice of modern governments. For example, John Locke's (1632-1704) idea of inalienable rights fits easily within the Quranic framework and the Universal Islamic Declaration of Human Rights (UIDHR) as does the idea of constraint upon the authorities and protection against official abuse of power [European Human Rights Reports, 4 (1981); UIDHR, Articles 6 and 12(c)]. The influence of Islamic political thought on the American constitutional system, is also possible, due to many similarities between the thought of Jefferson and other founding fathers and some basic Islamic ideas (Azizah Y. al-Hibri, 1999, 492). In any case, it has also been argued that generally, the democratic elements existed with the emergence of Islam and the latter inspired the Western democracy (Robert Briffault, 1919, 190-191). However, people's involvement in democracy is subject to certain limits and ethical requirements stipulated in shariah. It should be noted that al-Ghazali (1058-1111) is perfectly clear about the importance of constitutional law and explicitly indicates its superiority over the ruler himself (Haroon Khan Sherwani, 1942, 211).

\section{Studies in Islamic Constitutional Law}

The Islamic concepts of state, government and constitutional and administrative law are couched in general guiding principles. The classical works on Islamic political jurisprudence normally begins with the discussion on the importance and the responsibility of establishing the Islamic state, usually referred to as khilafah or imamah. Discussions are found in the works of Islamic jurisprudence ('ilm al-fiqh) and theology ('ilm al-kalam). Other aspects, among others, centered on the issues of leadership, Islamic legal rulings on the establishment of Islamic State, and qualifications and methods of election or appointment of khalifah and his functions.

However, early discussions on the various aspects of constitutional and administrative law are scattered in the various topics and branches of figh in the Islamic jurisprudence. In a modern context, studies on the subject, as an independent branch of Islamic law, are considered rudimentary, compared to those of other aspects of Islamic jurisprudence, and they have not been fully developed, based on observations by some prominent scholars on Islamic constitutional law, for example, 'Abd al-Razzaq al-Sanhuri and 'Abdul Hamid Mutawalli, and more recently, Professor Mohammad Hashim Kamali (2010, 1). It must however be admitted that there has been a growing number of works on Islamic politics, state 
and government in the twentieth century, and more recently in the early twenty first century. However, studies or writings addressing specifically and distinctively on Islamic constitutional and administrative law or Islamic constitutionalism in a contemporary parlance, are perhaps small in number, compared to other works on Islamic jurisprudence, and general works on Islamic state. Most writings, as stated earlier, concentrated on the conception of khilafah or imamah, together with other principles of Islamic state, government and the constitution, derived or discernable, from the Quran and Sunnah of the Prophet Muhammad (s.a.w).

Elaboration of the constitutional details and application of Islamic constitutional principles also depend on the doctrines of ijtihad, siyasah shar'iyyah and maqasid al-shar'iyyah. It is important to understand these doctrines in relation to constitutional law.

\section{Siyasah Shar'iyyah, Maqasid and Constitutional Law}

Generally, there are two meanings associated with siyasah shar'iyyah, given by Muslim jurists and scholars: first, it relates to political thought and administration of Islamic state; and second, a specific method to determine an Islamic legal rule based on public interest (Mahmood Zuhdi Hj Abdul Majid, 2003, 1-3) The term siyasah shar'iyyah has traditionally been used to refer to a special connotation, namely a particular branch of knowledge that deals with a study of the Islamic system of government (nizam al-hukm al-Islami or al-ahkam al-sultaniyyah) which discusses various topics relating to government administration. Its analysis also includes the discretionary power of rulers and judges in the determination and imposition of Islamic criminal punishments that are not specified in the Quran and Sunnah ('uqubah ta'ziriyyah or tafwidhiyyah). Perhaps, what has been suggested by Professor Mohamad Hashim Kamali is more acceptable. According to him, siyasah shariyyah is a broad doctrine of Islamic law which authorises a ruler to determine the manner in which the shariah should be administered. The ruler may accordingly take discretionary measures, enact rules and initiate policies considered necessary in the interest of good government, provided that no substantive principle of the shariah is violated thereby (Mohamad Hashim Kamali, $1989,59)$.

This broad description of siyasah shar'iyyah seems to be in accord with the several definitions given by some Muslim jurists. Literally, the term siyasah shar'iyyah means a shariah oriented policy. It applies to all government policies. However, the usage of the 
fuqaha' (Muslim jurists) associates the term with decisions and policy measures, taken by the leader of a country (ulu al-amr), on matters for which no specific ruling could be found in the shariah. It refers to an act based on public interest (maslahah), which the Quran and the Sunnah have neither upheld nor overruled, with a view to prevent harm, and bring the people closest to beneficence (solah), and protect them from corruption (fasad), without violating the general principles of shariah, and in harmony with the spirit and objectives of the shariah (maqasid al-shari'ah) (Abd al-Wahhab Khallaf, 1931, 3,14-5; Ibn al-Qayyim al-Jawziah, 1961, 16).

Siyasah in this sense, may entail adopting policies, and enacting laws in all spheres of government. This includes regulation of both domestic and foreign relations, constitutional, fiscal, administrative or judicial affairs (Mohamad Hashim Kamali, 1989, 61). The area of siyasah shar'iyyah falls in the second category of shariah rules which are considered flexible (al-murunah) and amenable to improvement, as opposed to another aspect of Islamic law known as permanent rules (al-thabat wa al-khulud) which are not subject to change or development (al-tatowwur) (al-Qaradawi, 1991, 246-7). Siyasah shar'iyyah denotes rules based on opinion and ijtihad whose purpose is to secure public interest and meet changing necessities and needs of life within the scope of moderation (i'tidal) without neglect (tafrit or ihmal) and exceeding the proper limits (ifrat) ('Abd al- 'Al Ahmad 'Utwah, 1993, 95).

In view of the limited and broad principles of Islamic constitutional and administrative law, specific details (tafasil or far'iyyat) on this matter are largely left to be determined by the doctrines of ijtihad dusturi and siyasah shar'iyyah which take into account the concept of maqasid al-shari'ah. The Arabic term maqasid (the plural for maqsad) literally means objectives, aims, purposes, intentions, spirits, principles, secrets and philosophy or wisdom. Maqasid al-shari'ah signifies the objectives of shariah which encapsulate the intentions and secrets ascertainable from the shariah as a whole or its specific rules. The primary goal of the shariah is to free the people from their unbridled human desires, and the Islamic mission is to bring mercy and kindness to the whole universe, not only to human beings, but also to all the creatures of God (rahmatan li al- 'alamin) (Quran, al-Anbiya': 107). Shariah is essentially hinged on safeguarding the best interests (ri'ayat or jalbu al- masolih) and avoiding corruption or what is bad or harmful (daf'u or dar'u al-mafasid or al-madorrah) for the entire human beings in this world and in the hereafter, without neglect of duties to take care of other creatures and the environment. The underlying basis of maqasid is the assumption that Allah has laid down the laws in the interest of the people. This implies that the law and the goals of 
the shariah are interwoven and always serve the best interest of mankind. This is consistent with the above Quran's main objective (Abdul Samat Musa, 2017, 104).

\section{The Islamic Constitutional Approach: Forms and Substance Distinguished}

Islam, though all embracing and comprehensive (syumul) in its scope, as asserted in the Quran, there has been a general consensus that, as far as state and constitution are concerned, it only laid down fundamental principles or features of state, or government, or constitution without dictating any specific details. Thus, there is no rigid scheme on which the edifice of government can be erected at all times and in all places. Although there are guiding principles and norms which are essential to be followed, in the domain of politics and statecraft, there is nothing as 'form of government' as the phrase connotes in modern political parlance, which may be discernable from the Holy Quran and the Hadith.

Thus, what is provided is only a loose framework on this matter, to enable the possible development of appropriate forms of government and patterns of the state needed, in order to suit all societies and situations, for the best interest of the ummah and all human beings. Certainly, there are fundamental principles which are basic, unchangeable, eternal and binding. It is these principles (substance) that distinguished an Islamic state from un-Islamic one. While these fundamental principles, translated in Islamic constitutional or political literatures in Arabic as mabadi' or qawa'id nizam al-hukm (fundamental principles of government) are permanent, the form of government or state or constitution (ashkal alhukumah or al-daulah or al-dustur) and specific details of Islamic state are flexible (marin or murunah), and may vary and be amenable to change or adjustment in order to correspond to the ever- changing needs and varied circumstances of the times.

Muhammad Asad, after conducting an objective examination of the political ordinances of Quran and Sunnah, made his conclusion as follows:

“...the Quran and Sunnah... do not lay down any specific form of state: that is to say, the shariah does not prescribe any definite pattern to which the Islamic state must conform, nor does it elaborate in detail a constitutional theory. The political law emerging from the context of Quran and Sunnah... gives us the clear outline of a political scheme capable of realization at all times and under all conditions of human life...Rigidly fixed enactments and institutions could not possibly do justice to this natural trend toward variation..." and beyond broad political principles, according to him, the shariah "leaves a vast field of constitution- 
making activity, of governmental methods, and of day-to-day legislation to the ijtihad of the time concerned" (Muhammad Asad, 1980. 22-3).

Consequently, there is no particular model or prototype for an Islamic state, and what is available is a set of principles, and it may take a variety of forms and be internally organised in different ways, provided that it conforms to those principles (Mohammad Hashim Kamali, $2010,20)$. It is therefore wrong to say that there could be but one form of state deserving the adjective "Islamic" (Muhammad Asad, 1980, 22). Muhammad Asad argued that by insisting that the political forms and procedures of a contemporary Islamic state must strictly follow the pattern evolved in the early period of Islam which is not the slightest warrant in the Quran or Sunnah, will make shariah impossible to be accepted as a practical proposition for the political exigencies of our time. This approach, described by him as 'sterile, formalistic views... of the nature and methods of an Islamic state', should be overcome by a more 'creative spirit' (Muhammad Asad, 1980, 98-99) in meeting the objectives of shariah in matters of state and government. Indeed, the Quran warns against seeking the regulation of every thing by express divine command, as that might make the framework rigid, and therefore burdensome (Quran, al-Ma'idah: 101-2). Specific system or form of a constitution should be based on the needs of different societies and places (Muhammad al-Mubarak, 1981, $52)$.

With regard to the differences between the binding and flexible aspects of constitutional law, Dr. Abu al-Ma'ati Abu al- Futuh observed:

" it is not the forms of government and administrative machineries practised at the time of the Prophet and his companions which are binding the present Muslims. They are at liberty to build a political structure and machinery as they think best and suitable with their needs by learning from past experiences of their predecessors and those of other societies, so that the best form or method could be derived, in order to realise the principles of justice, equality and consultation" $(1977,9)$

Thus, it is essential to have a clear picture about the Islamic approaches in matters concerning state, government and constitution, and the ability to differentiate between what is termed as substance (fundamental principles), or binding elements (al-jauhar), and what is regarded as form (al-shakl), or non-binding or flexible elements. The latter, though necessary, is changeable or reviewable and open to constant improvement or innovation or creativity, on 
the rider that they do not run counter to the essential principles and values (Abdul Samat Musa, 1997, 8).

\section{Principles of Islamic State, Government and Constitution}

Generally, state, government and constitution are governed by common principles. There are two approaches adopted by Muslim scholars in dealing with the principles of Islamic state, government or constitution (The terms state, government and constitution are used interchangeably to refer to the system of governance): First, a brief and concise analysis of their general principles or features (di'amah or mumayyizat), as advocated, for example, by 'Abdul Qadir 'Audah (1967, 72, 77); and secondly, a more detailed description of such principles (mabadi'), ascertained or derived from the Quran and Sunnah. Despite some differences in the enumeration of these principles and their formulation given by the Muslim jurists or scholars, the following may be considered basic and main or fundamental constitutional principles: (i) supremacy of shariah or religion of Islam (siyadat al-shari'ah aw al-Islam) or rule of law; (ii) vicegerency or Islamic leadership (khilafat), (iii) responsibility (mas'uliyyah), (iv) trust (amanah), (v) accountability ('urdoh li al-muhasabah), (vi) consultation (shura), (vii) justice ('adl), and (viii) rights and duties of a ruler (leader, government or state) and the ruled or the citizens or the people including non-Muslims (huquq wa wajibat al-raa'i wa al-ra'iyyah). There are, however, many other unique features, descriptions and characteristics of Islamic state given by Muslim scholars (Mustafa Kamal Wasfi, 1994, 11-27). These principles are universal in character, and relevant to the modern system of government and constitution, which should not unnecessary create fears among the non-Muslims. The following are brief explanations of some of those principles.

\section{Supremacy of Shariah (siyadat al-shari'ah)}

The concept of the supremacy of shariah (siyadat al-shari'ah) or rule of law means nothing is above the shariah as the ultimate reference. It eliminates the very basis of an absolute rule of man, which has often been the cause of corrupt practices and unbridled exercise of power. In other words, the concept represents a constitutional state (Yusuf Al-Qaradawi, 2015, 30). The primacy of shariah, does not imply that the Islamic oriented system is theocratic in a western sense, where the rights and freedom of the people, including non-Muslims are denied. Their interests, needs and welfare will always be taken into consideration, and they will be 
involved in decision making processes. Ample room is provided to the jurists, policy makers and the people, through the principles of ijtihad, shura and siyasah shar'iyyah, to work out required details, formulate policies and enact laws and regulations within the parameters of religion, its fundamentals and maqasid al-shari'ah (Abdul Samat Musa, 1998, 31).

\section{Concept of Leadership (al-khilafah)}

The concept of khilafah represents the continuation of the prophetic mission to bring mercy to all universe, and successive Islamic leaderships after the Prophet were meant, as a public mandate and religious responsibility, to safeguard the Islamic religion and manage the worldly affairs (hirasat al-din wa siyasat al-duniya) (Mawardi, 1960, 5). Another meaning is to lead the people in accordance with shariah for their own interests in this world and in the hereafter (Ibn Khaldun, 1960, 135). The terms Khalifah, Imam, Ulu al-Amr, Amir and Sultan mentioned in the Quran (al-Baqarah: 124; al-Furqan: 74; al-Isra': 71) or Hadith basically convey the same meaning which refer to top leadership of an Islamic state, and do not mean the names and terms as such. What is essential, however, is their expected functions and roles or their qualities. Thus, the people are allowed to adopt any acceptable name or title, to refer to the head of state or government.

The classical Islamic political theory seems to revolve around the concept of khilafat or imamat and the practice of successive Islamic governments after the demise of the Prophet Muhammad (s.a.w). However, the Islamic political theory is not about dictating a specifically binding form of state or constitution, but rather it refers generally to any system of government that conforms to, and comply with, fundamental shariah principles of state and government. What is meant by nizam al-khilafat or nizam al-hukm al-islami is any system of government that fulfills such principles regardless of its form (al-Mubarak, 1981, 56). Historically, caliphate represents both substance and form. However, in essence, Islamic leadership and political power are considered a trust (amanah) and must be discharged with full responsibility and accountability. The latter two principles are a religious duty to be individually and publicly fulfilled (al-Nisa', 58). The people are also given the right and the task to watch and check the executive action, through their representatives, or to be carried out directly. Thus, the executive body does not enjoy absolute power. 


\section{Concept of consultation or deliberation (al-shura)}

The principle of shura has many dimensions and can take many forms. It is politically mandatory upon a ruler or the government to consult the people in the administration of the state (Quran, Al 'Imran, 159), and considered one of the traits of Muslim community (Quran, al-Shura, 38). In the context of human rights, this principle confers political right on the citizens, including the rights to be consulted and to elect a leader and determine the suitable methods for his election or appointment. The corollary of this is the rights to check, watch and criticize (haq al-muhasabah, wa al-muraqabah wa al-naqd) the government, and the exercise of executive power and policies of the state, based on the principle of commanding what is good and prohibiting of what is bad (al-amr bi al-ma'ruf wa al-nahyu 'an al-munkar) and the concept advice (al-nasihah). Leaders must also be weighed in terms of their qualities, for example, capability (al-qawiy), trustworthiness (al-amin) and the best (al-aslah) (Ibn Taimiyyah, 1986, 35-37). The elements of democracy are already embedded in the principle of shura. Its methods and forms may vary according to different needs and circumstances. Thus, democracy is allowed, provided that Islamic values, principles and ethics are not violated (Abdul Samat Musa, 1998, 30-32; 1981). Shura must be exercised within its boundaries, without disputing what is considered fixed in the Quran and Hadith. In other words, it must be within the area of ijtihad, where differences in opinion are tolerable (Abdul Karim 'Uthman, 1968, 36).

The concepts of caliphate and shura are closely related, and both represent the aspirations of the people (siyadat al-sha'b) in the administration of the state, but under the guidance of the religion of Islam, which is manifested in the supremacy of shariah. Thus, in terms of legislative competence, legislative body in Islam, unlike United Kingdom's Parliament, is not supreme.

\section{Concept of Justice (al- 'adl)}

Another constitutional principle that attracted political philosophers across racial, religious and geographical divides is justice. The importance of justice has been given a great emphasis in the Quran and Hadith since the inception of Islam in the seventh century. The terms used in the Quran in reference to justice are al- 'adl, al-qist and al-mizan (Quran, alHadid; al-Nisa', 58-59; al-Nisa', 135). The concept of justice is comprehensive and universal. One of its important features is equality before the law (Hamidullah, 1973, 139). In the same 
vein, both sources condemn injustice and tyranny (zulm). A tyrant will not get protection of Allah and will be a loser (Maryam, 72; Yusuf, 23). The Islamic concept of justice is very comprehensive in its meaning and scope. It applies to all human dealings, whether in private or public spheres, or at an international level. This concept is particularly relevant to the administration of justice, executive formulation and execution of public policies, and the treatment of state or a ruler towards the people.

\section{Rights and Responsibilities (al-huquq wa al-wajibat)}

In Islamic constitutional theory, rights of the people (huquq al- insan) regardless of their racial origins and religious beliefs are also guaranteed, including freedom (al-hurriyyah) and equality (al-musawat) both of which have been made two separate constitutional or political principles by some Muslim scholars. Nevertheless, individual rights must always be accompanied with responsibilities of both rulers and the ruled, and should be exercised within certain limits (Abdul Samat Musa, 2003, 175-190). The rights that the people enjoy, entail government's obligation to fulfill them. Reciprocally, the government also enjoys the right to obedience (haq al-ta'ah), besides having to discharge public duties. Among the important functions of a government is to protect Islamic belief ('aqidah) and to help the weak and the needy. Another principle is social joint liability (al-takaful al-ijtima'i) which signifies that, besides promoting the spirit of mutual co-operation among the people, the government is particularly obliged to provide the basic necessities of life, especially to the poor and the unfortunate (Muhammad al-Mubarak, 1981, 21-22, 29-38).

Protection of human rights can be secured directly or indirectly through shariah objectives, fundamental constitutional principles of state, specific protections in the Quran and Sunnah, and general commands and prohibitions in the shariah (Abdul samat Musa, 2010, 9-12; 1994, 49-69). The protection human rights and the interests of the people are inherent in the shariah, and it is not the result of human political thought and historical developments as occurred in Western history (Abdul Samat Musa, 1988, 7-11, 516-520). Islam has its own approaches and routes to human rights, which are grounded in religious teachings (Abdul Samat Musa, 2013, 5). Rights are always accompanied with duties (wajibat). The integrated basis of religion and responsibilities are commended by Professor C. G. Weeramantary who is an expert in international law, when he said that the Islamic stress on relationship with the divine, and the concept of duty, could well lead to a more dedicated and purposive 
commitment to human rights than might be possible in a system which depends on concession grudgingly granted under compulsive pressure (C. G. Weeramantary, 1988, 123).

\section{What constitutes Islamic State and Constitution?}

There is no hard-and-fast definition of Islamic state in the Quran and Sunnah. Both sources only provide general rules related to state and government, as part of complete guidance for Muslims and the whole mankind. In classical works of Muslim jurists, Islamic state was termed as Dar al-Islam (abode of belief and peace), which later referred to as daulah Islamiyyah by Muslim scholars. The term and its definition did not exist in the Constitution of Madinah. There are, however, a number of definitions given by Muslim jurists from various schools of Islamic law, with some variations in terms of contents and formulation. Most definitions seem to have revolved around the implementation of shariah, Islamic top leadership, composition of population and freedom and security for Muslims to practise their religion. Another important general criterion used was the subordination or submission of state to the religion of Islam (tahkim al-Islam), in addition to the existing qualifications of state under international law (Abdul Samat Musa, 2004, 129). The additional element means that the country should be guided by the religion of Islam. However, as for the application of Islam or shariah, there is no quantification or degree of its implementation or detailed explanation, attached to such definitions in order for a country to qualify for an Islamic state.

There have been a lot of discussions and literatures by the Muslim jurists and contemporary Muslim scholars on the concepts and definitions of Islamic state, including by local Muslim religious experts. This clearly demonstrates that the issue of definition is a matter that falls within the realm of ijtihad (nitaq al-ijtihad), and the canvas is a subjective one and open to different interpretations. As for the Islamic constitution, focus of Islamic constitutional writings seems to be more on its fundamental principles, rather than providing definitions. Muslim scholars have used the same formulation to describe the meaning of a constitution as used in conventional constitutional definitions, and the constitution can take different forms, by taking into account different situations, provided that they are not contrary to the fundamental principles of Islamic religion (A-Sheikh Ibrahim al-Ni'mah, 2012, 35, 45). 


\section{Constitutional Practices and Application of Principles}

In the light of the various principles and interpretations derived from the Quran, Sunnah and previous practices of early Islamic governments, a Convention of the Ulama representing all the schools of Islamic thought was held from 21-24 January 1951, in Karachi, and issued the agreed statements on the basic principles of an Islamic State, but did not propose any particular form of government (Islam and the Modern World, Vol. 3, No. 4). Some Muslim scholars had made efforts to draft what they called 'Islamic Constitution', however, not specifically meant for a particular country. For example, the Islamic Research Academy of Al-Azhar appointed, in 1981, a committee of its scholars to work on the Islamic theory of state and its application in modern times. The committee was also entrusted with the task of drafting an Islamic constitutional model in accordance with shariah. In this draft, it is stated that Muslims form one single ummah. However, it is possible to have several nation states within the Islamic single ummah (ummatan waahidah) with different forms of government (Muhammad al-Ghazali, 1981). The nature of form or system of government is not eternal, but can be subject to a subsequent review if necessary, as in the case of the Constitution of the Islamic Republic of Pakistan 1973, where it was reviewed in 1983 by the Ansari Commission (Ansari Commission's Report on Form of Government, 1983).

Constitution can be drafted and adopted as a governing framework of a country. The Prophet Muhammad (s.a.w) had introduced the first written constitution (Hamidullah, 1981). The document was not only mentioned by Muslim historians and jurists, but also analysed later by Western scholars. Books on the history of Islam did not provide details on how the Constitution of Madinah was drafted. However, based on the policy of administration by the Prophet, he used to engage and consult the people about matters on which there was no revelation, including the drafting of this Constitution. This Constitution, referred to as Sohifah or Kitab, al-Wathiqah or al-Muwada'ah or al-Mu'ahadah (Sheikh Ibrahim alNi'mah, 2012, 91) contains provisions regulating various relationships in a multi-racial and multi-religious communities and ethnicities that existed then in Madinah, namely the relation between the Muslims and non-_Muslims, especially the Jews and other local inhabitants. The Constitution (Sohifah) also regulates the relationships between the Muhajirin (Emigrants) and Ansar (Helpers) and between the Prophet as a leader and the people or the ruled. 
The Sohifah is a practical example as to how both substance and variable elements are manifested in this historic and unprecedented document, and how the purposes of shariah are observed in its preparation. Among the important features discernable in this document are: final reference to God and the Prophet in the event of a dispute, promotion of Islamic brotherhood, cooperation with non-Muslims for the purposes of unity and defence of nascent State of Madinah against outside aggression, adoption of the system of government akin to federation or confederation, upholding justice and rule of law, protection of rights and freedom of the people, together with their duties and some measure of autonomy granted to various ethnic groups. Some of these features constitute fundamental principles, while others can be regarded as fulfilling local requirements and peculiar needs of a particular time and place. The drafting of a written constitution with its unique features was meant to achieve maslahah for the peoples of Madinah and ensure the sustainability of Islam and the ummah. The document also serves as a constitutional precedent for the Muslims and the world community at large (Abdul Samat Musa, 1979, 165-94).

\section{Islamic Constitutional Theory, Relevance and Challenges}

As previously examined, principles of Islamic state or constitutional law are universal in nature. While the Islamic constitutional theory is subservient to fundamental principles, its detailed application is flexible, and can fit into any structures of state, whether parliamentary, presidential, or monarchical or other forms and machineries of government. Because of the universal nature of the Islamic message, it offered a great potential for the development and enhancement of Islamic oriented constitutional law in Muslim countries.

There are, nevertheless, issues of interpretation and application, and lack of tolerance among some Muslims who regard the existing modern systems of government as something which is completely alien, or inimical to Islam, without a proper understanding of the true concept and reality in which such concept is to be applied. As a result, different approaches were adopted or certain actions taken in the name of establishing daulah Islamiyyah (Islamic state) or securing a political power. Perhaps, because of a lack of knowledge about Islam, or a misguided notion of Islamic state and jihad, some even resorted to extreme methods and unlawful means of struggle or change of government, which are against the holistic teachings of Islam, and shariah principles and objectives. Sometimes, the implication is fatal or destructive or divisive. Misconception may also create an internal conflict, fears and anxieties 
especially among the non-Muslims, as Islamic state has often been associated with alleged discrimination and deprivation of human rights, particularly those of non-Muslims and women. As it has been shown, this apprehension, from the true precepts of Islam, is without basis (Abdul Samat Musa, 2018, 98).

Thus, the real grasp of the Islamic constitutional approach is extremely imperative in any evaluation and determining the right course of action to be taken regarding the existing constitutional system, particularly in its application in contemporary situations. The true understanding of the correct relationship between Islam and state in the Islamic constitutional theory, and formulation of constitutional law, and how to realize the Islamic ideals of government in practice in a particular situation, is very important and significant, in enhancing the required relationship. The objective of having a constitutional document and other regulations, is basically to regulate the structure and powers of three main organs of state and determine their functions and relationships to ensure they act in accordance with law and certain norms (Abdul Samat Musa, 2015). The choice of a system of government is very much influenced by the circumstances of a particular nation. The other purpose of a constitution is to put some control on the exercise of power by state or government. The concept of a limited government underlining modern constitutionalism is in line with the objectives of shariah to uphold the principle of justice. The shariah has set certain limits where the rulers and the ruled are not allowed to transgress them. Abuse of power is considered an exercise of injustice (zulm), which is shunned and condemned in the Quran (Maryam, 72; Yusuf, 23).

The main challenge facing the Muslim world, as far as constitutional law is concerned, is how to translate those lofty Islamic ideals into modern and current constitutional law and practice. Apart from Islamic constitutional principles, there are other features and practices of good governance, which are in line with the precepts of Islam, for example, transparency, efficiency, integrity, openness, truth, quality, accountability, knowledge, sincerity and separation of power. The Islamic constitutional approach is not only about compliance with constitutional provisions, but also upholding other laws and constitutional practices that support the existing constitutional framework. For example, democratic rights enshrined in the constitution should be exercised in an ethical manner, and subject to certain limits, consistent with Islamic values. 


\section{Conclusion}

In Islamic constitutional perspective, the connection between Islam and state is an inseparable one. It has been argued and accepted that the governance of the affairs of the people and having power and political authority are a necessity in order to realize the comprehensive teachings of Islam. However, the notion of this interwoven relationship between religion and state sometimes gives rise to some issues of interpretation and application, including some misconceptions among some Muslims as well as non-Muslims. Islamic constitutional law, like other branches of law is deeply rooted in divine guidance, but at the same time, its approach is accommodating to contemporary environment. A proper understanding of the Islamic constitutional approach and the existing constitutional systems, will make the Muslims more tolerant, and the Islamic constitutional ideals more relevant in all situations. Now that all Muslim countries already have their own constitutions and political powers, the responsibilities lie in the executive authorities to enhance the Islamic ideals of state and government. The Muslim constitutional lawyers and scholars also have their role to play in the development of Islamic constitutional and administrative law, for example, in putting up better mechanisms, for the control of executive power, and enhanced protection of the rights and interests of the people, including suggesting remedies in case of their violation. Further, Islamic constitutional law is not only concerned with regulating the state and its institutions, but also the need to elect or appoint the right people to discharge the public duties entrusted to them.

*Professor of shariah and law at the Faculty of Syariah and Law, Universit Sains Islam Malaysia (USIM)

\section{References}

[1] Abdul Ghafur Hamid @ Khin Maung Sein. 2007. Public International Law: A Practical Approach. Petaling Jaya: Prentice Hall Pearson Malaysia Sdn. Bhd. Second Edition.

[2] 'Abdul Karim 'Uthman. 1968. Al-Nizam al-Siyasi fi al-Islam. Beirut: Dar al-Irshad.

[3] 'Abd al-Rahman Ibrahim al-Kailani. 2000. Qawa'id al-Maqasid 'Inda al-Imam al-Shatibi. Dimashq: Dar al-Fikr.

[4] Abdul Samat Musa. 2017. 'Maqasid al-Shariah and its Elements in the Federal Constitution' in Artikel 121(1A) Perlembagaan Persekutuan: Sejauh Manakah Artikel Ini 
Menyelesaikan Konflik Antara Mahkamah Syariah Dengan Mahkamah Sivil. Suntingan Abdul Monir Yaacob \& Nurul 'uyun Haji Zainal. Cyberjaya: Penerbit UIM.

[5] Abdul Samat Musa. 2015. 'Federal Constitution and Maqasid al-Syariah'. Paper presented at the 3rd International Seminar on Syariah and Common Law (ISCOL), held on 27 and 28 October 2015 at Universiti Sains Islam Malaysia (USIM).

[6] Abdul Samat Musa. 2018. Islam, State and the Constitution in Malaysia and Islamic Constitutional theory: Their Relationships and Challenges. Bandar Baru Nilai: USIM Press.

[7] Abdul Samat Musa and Zuliza Kusrin. 2002. Undang-Undang Perlembagaan Dan Pentadbiran. Bangi: Pusat Pengajian Jarak Jauh, Universiti Kebangsaan Malaysia.

[8] Abdu Samat Musa. 1979. Undang-Undang Perlembagaan: Satu Kajian Perbandingan Antara Negara-Negara Islam. Kuala Lumpur: Disertasi LL.M dikemukakan kepada Fakulti Undang-Undang, Universiti Malaya.

[9] Abdul Samat Musa. 1981. 'Antara Syura dan Demokrasi'. Panji Masyarakat. Kuala Lumpur: Keluaran Mei.

[10] Abdul Samat Musa. 2004. 'Hak dan Tanggungjawab Rakyat dan Ulil Amri'. Dalam. Konsep dan Peranan Ulil Amri di Malaysia. Kuala Lumpur: Institut Kefahaman Islam Malaysia.

[11] Abdul Samat Musa. 1994. 'Human Rights; An Overview of Islamic Dimensions'. In. Islamiyyat. No. 15. Bangi: Universiti Kebangsaan Malaysia.

[12] Abdul Samat Musa. 2013. 'Human Rights in Shariah and International Human Rights Instruments'. A working paper presented as an invited speaker at the International Conference on Human Rights in Shariah and International Rights Instruments (Huquq alInsan fi al-Shariah al-Islamiyyah wa al-Mawathiq al-Dauliyyah Li Huquq al-Insan), held at Makkah, organised by World Muslim League (Rabitah al-Alam al-Islami), 10- 12 October 2013.

[13] Abdul Samat Musa. 1997, 'Konsep Ketertinggian Dalam Perlembagaan: Satu Pengamatan Umum Dari Perspektif Perlembagaan Islam dan Malaysia'. Dalam. Isu Syariah dan Undang-Undang. Bangi: Jabatan Syariah, Fakulti Pengajian Islam, Universiti Kebangsaan Malaysia.

[14] Abdul Samat Musa. 2003. 'Tanggungjawab Pemerintah dan Kerajaan Terhadap Rakyat Serta Tanggungjawab Rakyat Terhadap Pemerintah dan Kerajaan'. Dalam. Islam, politik \& Kerajaan (Penyunting Khairul 'Azmi Mohamad dll). Johor Bahru: Tinta Perdana Sdn Bhd. 
[15] Abdul Samat Musa. 2004. 'Perlembagaan (Constitutionalism): Antara Islam dan Barat'. Dalam. Syariah dan Undang-Undang; Suatu Perbandingan. Suntingan Zaini Nasohah et al. Kuala Lumpur: Utusan Publications \& Distributors Sdn Bhd.

[16] Abdul Samat Musa. 2010. 'Ciri-Ciri Faham dan Amalan Hak Asasi Islami'. Kertas Kerja dibentangkan sebagai pembentang jemputan di Seminar Agama dan Hak Asasi Manusia: Kearah Pemurnian Kefahaaman. Kuala Lumpur: Anjuran Institut Kefahaman Islam Malaysia (IKIM), pada 22-23 Jun 2010.

[17] Abdul Samat Musa. 1998. 'Islam dan Teori Undang-undang Perlembagaan dan Pentadbiran'. Isu Syariah dan Undang-Undang. Bangi: Pusat teknologi pendidikan UKM.

[18] Abdul Samat Musa. 2014. 'Perlembagaan Madinah'. Working Paper presented at Kolokium Islam Pahang “Meraikan Ilmu”, as an invited presenter, 17-19 March 2014.

[19] Azizah Y. al-Hibri. 1999. 'Islamic and American Constitutional Law: Borrowing Possibilities or a History of Borrowing?'. University of Pennsylvania Journal of Constitutional Law. Vol. 1: 3 .

[20] C. G. Weeramantry. 1988. Islamic Jurisprudence An International Perspective. London: The Macmillan Press Ltd.

[21] Hamid Enayat. 1982. Modern Islamic Political Thought. London: Macmillan Press Limited.

[22] Haroon Khan Sherwani. 1942. Early Muslim Political Thought and Administration. Delhi: Jayyed Press. First edition.

[23] Ibn Khaldun. 1960. Al-Muqaddimah. Qahirah: Dar Ahya' al-Kutub.

[24] Ibn Taimiyyah. 1986. Al-Siyasah al-Shar'iyyah fi Islahi al-Ra'i wa al-Ra'iyyah. Kuwait: Dar al-Arqam Li al-Nashr wa al-Tauzi’.

[25] Kevin YL Tan. 2014. An Introduction to Singapore's Constitution. Singapore: Talisman Publishing Pte Ltd. Third edition.

[26] Mahmood Zuhdi Hj Abdul Majid. 'Teori Politik Islam: Memahami Siasah Syar'iyyah'. Islam, Politik \& Kerajaan (Penyunting Khairul ‘Azmi Mohamad dll). Johor Bahru: Tinta Perdana Sdn Bhd.

[27] Mawardi. 1960. Al-Ahkam al-Sultaniyyah. Qahirah: Matba'ah Mustafa al-Babi al-Halabi wa Auladih.

[28] Mohamed Salleh bin Abas. 1968. Prinsip Perlembagaan dan Pemerentahan Di-Malaysia. Kuala Lumpur: Dewan Bahasa dan Pustaka. Cetakan Pertama.

[29] Muhammad 'Ali al-Sobuni. 1981. Sofwatu al-Tafasir. Beirut: Dar al-Quran al-Karim. Al-Mujallad al-Thani. al-Tab'ah al-Rabi'ah. 
[30] Mohammad Hashim Kamali. 2010. 'Constitutionalism and Democracy: an Islamic Perspective'. Paper presented at the International Conference on Religion, Law and Governance in Southeast Asia'. Kuala Lumpur: International Institute of Advanced Islamic Studies.

[31] Muhammad al-Mubarak. 1981. Nizam al-Islam fi al-Hukmi wa al-Daulah. Dar al-Fikr: aAi-Tab'ah al-Rabi'ah.

[32] Muhammad al-Ghazali. 1981. 'Introduction to A Draft of Islamic Constitution'. Islamic Studies. Vol. XX, Summer.No. 2.

[33] Muhammad Hamidullah. 1973. The Muslim Conduct of State. Lahore: Ashraf Press. Sixth Edition.

[34] Muhammad Hamidullah. 1975. The First Written Constitution in the World. Lahore: Ashraf Press. Second Edition.

[35] Mustafa Kamal Wasfi. 1994. Al-Nizam al-Dusturi fi al-Islam Muqaranan bi al-Nuzum al-'Asriyyah, Qahirah: Maktabah Wahbah.

[36] Robert Briffault. 1919. The Making of Humanity. London: George Allen \& Unwin.

[37] Sheikh Ibrahim al-Ni'mah. 2012. Usul al-Tashri' al-Dusturiy fi al-Islam. Dar al-Furqan li al-Nashr wa al-Tauzi'.

[38] Sir Ivor Jennings. 1973. The Law and the Constitution. Great Britain: Biddles Ltd. Fifth Edition.

[39] Yusuf al-Qaradawi. 1991. Madkhal Lidirasat al-Shari'ah al-Islamiyyah. Qahirah : Maktabah Wahbah.

[40] Yusuf al-Qaradawi. 2015. Fiqh Daulah Menurut Perspektif Islam (Translation). Selangor: Percetakan Mihas Sdn Bhd.

[41] Muhammad Asad. 1980. The principles of State and Government in Islam. Gibraltar: Dar al-Andalus Limited. New Edition. 